\title{
ANTIFUNGAL SUSCEPTIBILITIES OF CLINICAL AND ENVIRONMENTAL ISOLATES OF Cryptococcus neoformans IN GOIÂNIA CITY, GOIÁS, BRAZIL
}

\author{
Lúcia Kioko Hasimoto SOUZA(2), Orionalda de Fátima Lisboa FERNANDES(1), Cláudia Castelo Branco Artiaga KOBAYASHI(1), Xisto Sena PASSOS(1),
} Carolina Rodrigues COSTA(1), Janine Aquino LEMOS(1), Ary Henrique SOUZA-JÚNIOR(2) \& Maria do Rosário Rodrigues SILVA(1)

\begin{abstract}
SUMMARY
We evaluated the antifungal activities of amphotericin B, fluconazole, itraconazole and voriconazole in 70 Cryptococcus neoformans strains obtained from cerebrospinal fluid from AIDS patients and 40 C. neoformans strains isolated from the environment. Four clinical isolates were identified as $C$. neoformans var. gattii. The susceptibility test was done using a broth microdilution method according to NCCLS M27-A2. Range minimal inhibitory concentrations (MICs) for C. neoformans clinical isolates were $0.06-1.0 \mu \mathrm{g} / \mathrm{mL}$ for amphotericin $\mathrm{B}, 0.125-8 \mu \mathrm{g} / \mathrm{mL}$ for fluconazole, $0.03-0.5 \mu \mathrm{g} / \mathrm{mL}$ for itraconazole and $0.03-0.25 \mu \mathrm{g} / \mathrm{mL}$ for voriconazole. C. neoformans environmental isolates showed range MICs $0.015-0.125 \mu \mathrm{g} / \mathrm{mL}, 0.25-2.0 \mu \mathrm{g} / \mathrm{mL}, 0.007-0.125 \mu \mathrm{g} / \mathrm{mL}$ and $0.03-0.25 \mu \mathrm{g} / \mathrm{mL}$ for amphotericin B, fluconazole, itraconazole and voriconazole respectively. The MICs results obtained from clinical and environmental isolates showed similar pattern of susceptibility and no resistance has been found in our isolates.
\end{abstract}

KEYWORDS: Cryptococcus neoformans; Antifungal agents; Cerebrospinal fluid; Environment.

\section{INTRODUCTION}

Cryptococcus neoformans is an encapsulated, spherical yeast of which three varieties are recognized, C. neoformans var. neoformans (serotypes $\mathrm{D}$ and $\mathrm{AD}$ ), $C$. neoformans var. grubii (serotype $\mathrm{A}$ ) and $C$. neoformans var. gattii (serotypes B and C). The neoformans and grubii varieties have a worldwide distribution, and it is associated with soil contaminated with bird droppings. C. neoformans var. neoformans is generally responsible for cryptococcosis in immunocompromised patients, particularly in HIV infected individuals ${ }^{1,6,22,24}$. C. neoformans var. gattii is geographically restricted to tropical and subtropical climates, and it is most commonly found in association with Eucalyptus camaldulensis and E. tereticornis trees ${ }^{5,13,16}$. This variety causes infection in apparently healthy hosts and it is considered as a true pathogen $3,11,27$. C. neoformans infection occurs after inhalation from environmental sources, of yeast cells into the lung, with hematogenous dissemination to the central nervous system, where causes cryptococcal meningitis, the most common and serious cryptococcal disease manifestation ${ }^{26}$.

Until now, the currently accepted therapies for cryptococcosis are limited to amphotericin B, 5-fluorocytosine and fluconazole ${ }^{4}$. However, the treatment drugs for cryptococcosis are not satisfactory, because of their toxicity, their limited ability to clear infections completely, accompanied by the development of resistance in fungi ${ }^{1}$. Thereby, methods for testing the antifungal susceptibility of $C$. neoformans should become important tools for the selection and monitoring of appropriate antifungal drugs for the treatment and prophylaxis of cryptococcal infections.

By the fact that there are few comparative studies carried out on antifungal susceptibilities from environmental and clinical $C$. neoformans isolates, the purpose of this investigation was to verify the in vitro susceptibility of 110 C. neoformans isolates (70 clinical and 40 environmental) towards four antifungal agents, including fluconazole, itraconazole, voriconazole and amphotericin B, using the broth microdilution method ${ }^{19}$.

\section{MATERIALS AND METHODS}

1. Organisms: A total of 110 C. neoformans isolates were included in this study. They comprised 70 clinical strains isolated from cerebrospinal fluid from AIDS patients and 40 environmental isolates from pigeon excreta and from Eucalyptus trees, originated from Goiânia city, located in Midwest region of Brazil. C. neoformans was identified by colonial and cellular morphologies and physiological and biochemical characteristics ${ }^{10}$. The varieties were determined in canavanine-glycine-bromothymol blue agar $(\mathrm{CGB})^{12}$. These isolates were stored at $4{ }^{\circ} \mathrm{C}$ on Sabouraud dextrose agar slants (Difco) and subcultured $72 \mathrm{~h}$ prior the test.

2. Antifungal susceptibility testing: Standard broth microdilution method recommended by the NCCLS M27-A2 ${ }^{12}$ was used. 


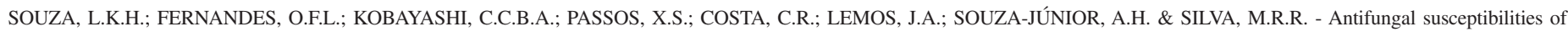
clinical and environmental isolates of Cryptococcus neoformans in Goiânia City, Goiás, Brazil. Rev. Inst. Med. trop. S. Paulo, 47(5): 253-256, 2005.

2.1. Antifungal agents: Amphotericin $B$ (Fungizone, Squibb, USA), itraconazole (Jansen Pharmaceuticals, Beerse, Belgium) and voriconazole (Pfizer Pharmaceutical Group) were dissolved in dimethyl sulfoxide, and fluconazole (Pfizer International, New York, USA) was dissolved in distilled water. Further dilutions of each antifungal agent were prepared with RPMI 1640 medium (Sigma) containing Lglutamine without sodium bicarbonate, and buffered to a $\mathrm{pH} 7.0$ with 0.165M morpholinepropanesulfonic acid (MOPS) (Sigma).

2.2. Inoculum: The suspension of yeast from 48 -h-old cultures was prepared in sterile saline $(0.85 \%)$ adjusted with a spectrophotometer to a cell density of $0.5 \mathrm{McFarland}$ standard at a wavelength of $530 \mathrm{~nm}$. This suspension was diluted at 1:50 followed by a 1:20 dilution in RPMI 1640 in order to obtain a final concentration of $1 \times 10^{3}$ to $5 \times 10^{3} \mathrm{CFU} / \mathrm{mL}$.

2.3. Susceptibility testing: Microtitre plates were covered with $100 \mu \mathrm{L}$ of different concentrations of the antifungal agents and added with $100 \mu \mathrm{L}$ of the yeast suspension. A final inoculum of $0.5 \times 10^{3}$ to $2.5 \times 10^{3} \mathrm{CFU} / \mathrm{mL}$ and the final concentrations of the antifungal agents ranged from 0.03 to $64 \mu \mathrm{g} / \mathrm{mL}$ for fluconazole and 0.007 to $16 \mu \mathrm{g} / \mathrm{mL}$ for itraconazole, voriconazole and amphotericin B. These plates were incubated at $35^{\circ} \mathrm{C}$ and read after 72 hours. The MIC end points were defined for amphotericin B as the lowest concentration of drug which resulted in a complete inhibition of visible growth, while for the three azoles were defined as the lowest concentration of drug that produced a $80 \%$ reduction in fungal growth compared to that one of drug-free growth control. All susceptibility tests were performed twice by each antifungal agent.

3. Quality control: Quality control organism Candida parapsilosis ATCC 22019 was included on each day of testing to check the accuracy of the drug dilutions and the reproducibility of the results. The purity and viability of all tested organisms were checked subculturing the inoculum suspension in Sabouraud dextrose agar (Difco).

As the breakpoint susceptibility values have not yet been proposed by the NCCLS M27-A2 ${ }^{12}$ for C. neoformans, the resistance to antifungal agents considered for fluconazole was $\geq 64 \mu \mathrm{g} / \mathrm{mL}$, for itraconazole and voriconazole $\geq 1 \mu \mathrm{g} / \mathrm{mL}$ and $\geq 2 \mu \mathrm{g} / \mathrm{mL}$ for amphotericin $\mathrm{B}^{14,17,20,24}$.

\section{RESULTS}

From the 70 clinical isolates obtained from AIDS patients cerebrospinal fluid, 66 were identified as C. neoformans var. neoformans and four as $C$. neoformans var. gattii. All environmental isolates were identified as $C$. neoformans var. neoformans.

All C. neoformans isolates were susceptible to amphotericin B, fluconazole, itraconazole and voriconazole. However, MIC values of the clinical isolates for all tested antifungal drugs were higher than for the environmental isolates. The analysis of $\mathrm{MIC}_{50}$ and $\mathrm{MIC}_{90}$ values showed that the major difference between clinical and environmental isolates was verified for amphotericin $\mathrm{B}$. $\mathrm{MIC}_{50}$ values for clinical isolates were fourfold higher than that for environmental isolates for this drug.

The MIC ranges and MIC required to inhibit 50\% and $90 \%$ for amphotericin $\mathrm{B}$, fluconazole, itraconazole and voriconazole are summarized in Table 1. The MICs for organism control C. parapsilosis ATCC 22019 tested in the experiments were consistently in agreement with those from the NCCLS reference results.

The MICs of amphotericin B, itraconazole and voriconazole for four clinical isolates of $C$. neoformans var. gattii showed low values, while for fluconazole the range MICs was $4-8 \mu \mathrm{g} / \mathrm{mL}$. The results of MIC values for each $C$. neoformans var. gattii are presented in Table 2.

\section{DISCUSSION}

Although cryptococcosis is the sixth most common opportunistic infection among HIV positive patients in $\mathrm{Brazil}^{8}$, little is known of this disease in Goiânia City, State of Goiás.

The varieties in this study were determined in CGB medium and C. neoformans var. neoformans predominated in isolates from environmental and clinical sources followed by $C$. neoformans var. gattii. Previous reports has shown $C$. neoformans var. neoformans as prevalent in Brazil ${ }^{7,9,21}$. Interestingly, a number of epidemiological studies have demonstrated that almost all cryptococcal infections in AIDS patients are due to the neoformans variety, that has long been known to be associated with pigeon excreta ${ }^{6,22}$. Limited exposure of HIV-infected patients to $C$. neoformans var. gattii can result in fewer infections by this variety. In spite of seeking $C$. neoformans var. gattii in environment, including eucalyptus trees, we are unable to isolate it.

The in vitro susceptibilities of $C$. neoformans strains to different antifungal drugs have been studied by a number of investigators ${ }^{2,15,18,24}$. However, there is few comparison of MIC data between clinical and environmental isolates. Our results showed similarity in the pattern of susceptibility in concern to the origin of the isolates (clinical or environmental). Testing antifungal susceptibility for environmental isolates may serve to evaluate the patterns of susceptibility of clinical isolates from the same geographic areas. The exposure to $C$. neoformans isolates could be associated with the infection risk in a given population.

In spite of fluconazole being the drug that commands maintenance treatment protocols for AIDS patients, in the present study, the highest MICs were detected for this drug. Other reports have demonstrated lower in vitro activity of fluconazole compared with other azoles ${ }^{4,23}$. SOARES et al. $^{24}$ by using the EUCAST broth microdilution method, obtained $C$. neoformans isolates from pigeons resistant to fluconazole. The lowest activity in vitro and the highest one in vivo can be explained by plasmatic levels of fluconazole that can be higher that other azoles as itraconazole ${ }^{18}$.

Although all the tested isolates have been susceptible to fluconazole, C. neoformans var. gattii isolates exhibited relatively higher MIC values than $C$. neoformans var. neoformans. Interestingly, infections due to C. neoformans var. gattii often require prolonged antifungal therapy ${ }^{24}$.

As it was seen in Tables 1 and 2, our MIC ranges obtained for amphotericin B allow us to conclude that the studied clinical and environmental isolates are susceptible to this drug. Amphotericin B is considered the treatment of choice for the initial stages of therapy and it is known that reports about amphotericin B resistance $C$. neoformans isolates are scarce. 


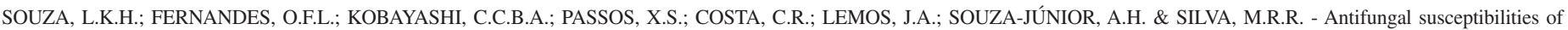
clinical and environmental isolates of Cryptococcus neoformans in Goiânia City, Goiás, Brazil. Rev. Inst. Med. trop. S. Paulo, 47(5): 253-256, 2005.

Table 1

Antifungal activities of amphotericin B and azoles derivatives against 70 clinical and 40 environmental isolates of $C$. neoformans as determined by broth microdilution method

\begin{tabular}{|c|c|c|c|}
\hline \multirow[t]{2}{*}{$\begin{array}{l}\text { Antifungal agents } \\
\text { and strain group* }\end{array}$} & \multicolumn{3}{|c|}{$\begin{array}{c}\text { Minimal Inhibitory } \\
\text { Concentration }(\mu \mathrm{g} / \mathrm{mL})\end{array}$} \\
\hline & Range & $\mathrm{MIC}_{50}$ & $\mathrm{MIC}_{90}$ \\
\hline \multicolumn{4}{|l|}{ Amphotericin B } \\
\hline clinical & $0.06-1.0$ & 0.5 & 0.5 \\
\hline environmental & $0.015-0.125$ & 0.06 & 0.125 \\
\hline \multicolumn{4}{|l|}{ Fluconazole } \\
\hline clinical & $0.125-8$ & 2.0 & 4.0 \\
\hline environmental & $0.25-2.0$ & 1.0 & 1.0 \\
\hline \multicolumn{4}{|l|}{ Itraconazole } \\
\hline clinical & $0.03-0.5$ & 0.06 & 0.125 \\
\hline environmental & $0.007-0.125$ & 0.03 & 0.125 \\
\hline \multicolumn{4}{|l|}{ Voriconazole } \\
\hline clinical & $0.03-0.25$ & 0.06 & 0.125 \\
\hline environmental & $0.03-0.25$ & 0.06 & 0.125 \\
\hline
\end{tabular}

*Clinical isolates: C. neoformans var. neoformans $\mathrm{n}=66$; C. neoformans var. gattii $\mathrm{n}=4$; Environmental isolates: $C$. neoformans var. neoformans $\mathrm{n}=40$

Table 2

Antifungal activities of amphotericin $\mathrm{B}$ and azoles derivatives against $C$. neoformans var. gattii clinical isolates as determined by broth microdilution method

\begin{tabular}{lcccc}
\hline Isolates & \multicolumn{4}{c}{ Minimal Inhibitory Concentration $(\mu \mathrm{g} / \mathrm{mL})$} \\
& Amphotericin B & Fluconazole & Itraconazole & Voriconazole \\
\hline L1 & 0.25 & 4.0 & 0.125 & 0.5 \\
L9 & 0.125 & 4.0 & 0.125 & 0.125 \\
L20 & 0.25 & 8.0 & 0.06 & 0.25 \\
L48 & 0.25 & 4.0 & 0.25 & 0.06 \\
\hline
\end{tabular}

Besides fluconazole, products currently available, voriconazole and itraconazole, appear to represent interesting alternatives for AIDS patients maintenance treatment. Voriconazole and itraconazole demonstrate excellent in vitro activity against $C$. neoformans ${ }^{23}$. As showed in Table 1, all strains were highly sensitive to two azoles; $90 \%$ of the isolates showed a minimum inhibitory concentration of 0.125 $\mu \mathrm{g} / \mathrm{mL}$ for the two antifungal agents.

In conclusion although no resistance has been found in our isolates, we continue paying attention to the emerging resistance to azoles, mainly fluconazole which should be searched, due to the widespread use of fluconazole as primary prophylaxis in AIDS patients.

\section{RESUMO}

\section{Suscetibilidade antifúngica de isolados clínicos e ambientais de Cryptococcus neoformans na cidade de Goiânia, Goiás, Brasil}

A atividade antifúngica de anfotericina $\mathrm{B}$, fluconazol, itraconazol e voriconazol foi avaliada em 70 amostras de Cryptococcus neoformans isoladas de liquido céfalo raquidiano (LCR) de pacientes com AIDS e em 40 amostras de $C$. neoformans obtidas do meio ambiente. Dentre os isolados 66 foram identificados como C. neoformans var. neoformans e quatro isolados clínicos, como $C$. neoformans var. gattii. Para a realização dos testes de suscetibilidade foi utilizado o método de microdiluição em meio líquido segundo o NCCLS M27-A2. As concentrações inibitórias mínimas (CIMs) para os isolados clínicos variaram de $0,06-1,0 \mu \mathrm{g} / \mathrm{mL}$ para anfotericina $\mathrm{B}, 0,125-8 \mu \mathrm{g} / \mathrm{mL}$ para fluconazol, $0,03-0,5 \mu \mathrm{g} / \mathrm{mL}$ para itraconazol e $0,03-0,25 \mu \mathrm{g} / \mathrm{mL}$ para voriconazol, enquanto que para as amostras ambientais de $C$. neoformans as concentrações inibitórias variaram de 0,015-0,125 $\mu \mathrm{g}$ / $\mathrm{mL}, 0,25-2,0 \mu \mathrm{g} / \mathrm{mL}, 0,007-0,125 \mu \mathrm{g} / \mathrm{mL}$ e $0,03-0,25 \mu \mathrm{g} / \mathrm{mL}$ para anfotericina $\mathrm{B}$, fluconazol, itraconazol e voriconazol, respectivamente. Os resultados das concentrações inibitórias mínimas obtidas para os isolados clínicos e ambientais mostraram semelhança com relação ao perfil de suscetibilidade, não tendo sido encontrados isolados resistentes a nenhum dos antifúngicos, levando-se em consideração a metodologia e critério de interpretação estudados.

\section{ACKNOWLEDGMENTS}

We are grateful to $\mathrm{CNPq}$ for the financial support (Process $\mathrm{n}^{\circ}$ 471703/2003-6) and Pfizer Pharmaceutical Group for donating the voriconazole.

\section{REFERENCES}

1. CASADEVAlL, A. \& PERFECT, J.R. - Cryptococcus neoformans. Washington, American Society for Microbiology, 1998.

2. CHANDENIER, J.; ADOU-BRYN, K.D.; DOUCHET, C. et al. - In vitro activity of amphotericin B, fluconazole and voriconazole against 162 Cryptococcus neoformans isolates from Africa and Cambodia. Europ. J. clin. Microbiol. infect. Dis., 23: 506 $508,2004$.

3. CHEN, S.; SORRELL, T.; NIMMO, G. et al. - Epidemiology and host- and varietydependent characteristics of infection due to Cryptococcus neoformans in Australia and New Zealand. Australasian Cryptococcal Study Group. Clin. infect. Dis., 31: 499-508, 2000.

4. DATTA, K.; JAIN, N.; SETHI, S. et al. - Fluconazole and itraconazole susceptibility of clinical isolates of Cryptococcus neoformans at a tertiary care centre in India: a need for care. J. Antimicrob. Chemother., 52: 683-686, 2003.

5. ELLIS, D. \& PFEIFFER, T.J - Natural habitat of Cryptococcus neoformans var. gattii. J. clin Microbiol., 28: 1642-1644, 1990.

6. FERNANDES, O.F.L.; COSTA, T.R.; COSTA M.R. et al. - Cryptococcus neoformans isolados de pacientes com AIDS. Rev. Soc. bras. Med. trop., 33: 75-78, 2000.

7. FRANZOT, S.P. \& HAMDAN, J.S. - In vitro susceptibilities of clinical and environmental isolates of Cryptococcus neoformans to five antifungal drugs. Antimicrob. Agents Chemother., 40: 822-824, 1996.

8. GUIMARÃES, M.D.C. - Estudo temporal das doenças associadas à AIDS no Brasil, 1980-1999. Cad. Saúde públ. (Rio de J.), 16 (suppl. 1): 21-36, 2000.

9. HORTA, J.A.; STAATS, C.C.; CASALI, A.K. et al. - Epidemiological aspects of clinical and environmental Cryptococcus neoformans isolates in Brazilian State Rio Grande do Sul. Med. Mycol., 40: 565-571, 2002.

10. KURTZMAN, C.P. \& FELL, J.W. - The yeasts, a taxonomic study. 4. ed. Amsterdam, Elsevier, 1998. 


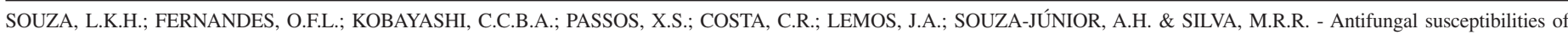
clinical and environmental isolates of Cryptococcus neoformans in Goiânia City, Goiás, Brazil. Rev. Inst. Med. trop. S. Paulo, 47(5): 253-256, 2005.

11. KWONG-CHUNG, K.J. - Cryptococcus neoformans. In: KWONG-CHUNG, K.J. \& BENNETT, J.E. Medical Mycology. Philadelphia, Lea \& Febiger, 1992. p. 397466.

12. KWONG CHUNG, K.J.; POLACHECK, I. \& BENNETT, J.E. - Improved diagnostic medium for separation of Cryptococcus neoformans var. neoformans (serotypes A and D) and Cryptococcus neoformans var. gattii (serotypes B and C). J. clin. Microbiol., 15: 535-537, 1982.

13. LICEA, B.A.; GARZA, D.G.; URBIETA, V.F. \& OLIVARES, R.A.C. - Aislamiento y caracterización de Cryptococcus neoformans var. gattii a partir de muestras de Eucalyptus camaldulensis en la ciudad de México. Rev. iberoamer. Micol., 16: 4042, 1999.

14. LOZANO-CHIU, M.; PAETZNICK, V.L.; GHANNOUM, M.A. \& REX, J.H. - Detection of resistance to amphotericin B among Cryptococcus neoformans clinical isolates: performances of three different media assessed by using E-test and National Committee for Clinical Laboratory Standards M27-A methodologies. J. clin. Microbiol., 36: 2817-2822, 1998.

15. MAXWELL, M.J.; MESSER, S.A.; HOLLIS, R.J.; DIEKEMA, D.J. \& PFALLER, M.A. - Evaluation of Etest method for determining voriconazole and amphotericin B MICs for 162 clinical isolates of Cryptococcus neoformans. J. clin. Microbiol., 41: 97-99, 2003.

16. MONTENEGRO, H. \& PAULA, C.R. - Environmental isolation of Cryptococcus neoformans var. gattii and Cryptococcus neoformans var. neoformans in the city of São Paulo, Brazil. Med. Mycol., 38: 385-390, 2000.

17. MONDON, P.; PETTER, R.; AMALFITANO, G. et al. - Heteroresistance to fluconazole and voriconazole in Cryptococcus neoformans. Antimicrob. Agents Chemother., 43: $1856-1861,1999$

18. MORAES, E.M.; PRÍMOLA, N.S. \& HAMDAN, J.S. - Antifungal susceptibility of clinical and environmental isolates of Cryptococcus neoformans to four antifungal drugs determined by two techniques. Mycoses, 46: 164-168, 2003.
19. NATIONAL COMMITTEE FOR CLINICAL LABORATORY STANDARDS Reference method for broth dilution antifungal susceptibility testing of yeasts: approved standard. Villanova, NCCLS, 2002. v. 17, No. 9. (Document M27-A2).

20. NGUYEN, M.H. \& YU, C.Y. - In vitro comparative efficacy of voriconazole and itraconazole against fluconazole-susceptible and -resistant Cryptococcus neoformans isolates. Antimicrob. Agents Chemother., 42: 471-472, 1998.

21. NISHIKAWA, M.M.; LAZERA, M.S.; BARBOSA, G.G. et al. - Serotyping of 467 Cryptococcus neoformans isolates from clinical and environmental sources in Brazil: analysis of host and regional patterns. J. clin. Microbiol., 41: 73-77, 2003.

22. OHKUSU, M.; TANGONAN, N.; TAKEO, K. et al. - Serotype, mating type and ploidy of Cryptococcus neoformans strains isolated from patients in Brazil. Rev. Inst. Med. trop. S. Paulo, 44: 299-302, 2002.

23. PFALLER, M.A.; ZHANG, J. \& MESSER, S.A. - In vitro activities of voriconazole, fluconazole, and itraconazole against 566 clinical isolates of Cryptococcus neoformans from the United States and Africa. Antimicrob. Agents Chemother., 43: $169-171,1999$

24. SOARES, M.C.B.; PAULA, C.R.; DIAS, A.L.T.; CASEIRO, M.M. \& COSTA, S.O.P. Environmental strains of Cryptococcus neoformans variety grubii in the city of Santos, SP, Brazil. Rev. Inst. Med. trop. S.Paulo, 47: 31-36, 2005.

25. SORRELL, T.C. - Cryptococcus neoformans variety gattii. Med. Mycol., 39: 155-168, 2001.

26. STEENBERGEN, J.N. \& CASADEVALL, A. - The origin and maintenance of virulence for the human pathogenic fungus Cryptococcus neoformans. Microbes Infect., 5: 667-675, 2003.

27. TAYLOR, M.B.; CHADWICK, D. \& BARKHAM, T. - First reported isolation of $C$. neoformans var. gattii from a patient in Singapore. J. clin. Microbiol., 40: 3098 3099, 2002.

Received: 4 May 2005

Accepted: 4 August 2005 